

Jurnal Basicedu Volume 5 Nomor 1 Tahun 2021 Halaman 133-139

JURNAL BASICEDU

Research \& Learning in Elementary Education

https://jbasic.org/index.php/basicedu

\title{
Pengembangan Perangkat Pembelajaran Berbasis Pendekatan Problem Based Learning di Sekolah Dasar
}

\author{
Novri Yaldi ${ }^{1}$, Ermawita ${ }^{2}$ \\ Institut Pendidikan Tapanuli Selatan, Padang Sidempuan, Indonesia ${ }^{1,2}$ \\ Email: yaldinovri@gmail.com ${ }^{1}$,ermajuwita91@ gmail.com ${ }^{2}$
}

\begin{abstract}
Abstrak
Hasil penelitian akan membawa peneliti dalam keberhasilan perangkat pembelajaran yang dikembangkan yang dinyatakan valid, praktis, dan efektif. Penelitian menggunakan pengembangan Four-D yaitu pendefinisian, perancangan, pengembangan, dan penyebaran. Hasil penelitian yang diperoleh dari penilaian validator ahli untuk produk yang dirancang berada pada persentase 81\%-100\%. Hasil pengisian lembar observasi keterlaksanaan RPP yang dilakukan oleh guru diketahui bahwa persentase nilai rata-ratanya adalah 95\%. Persentase rata-rata respon guru terhadap bahan ajar dan LKS yang digunakan 93,83\% yang berada pada kategori sangat praktis. Hasil angket respon siswa yang dibagikan setelah proses pembelajaran juga menunjukkan praktikalitas perangkat pembelajaran pada kategori praktis dengan persentase untuk bahan ajar $85,2 \%$ dan LKS $84,66 \%$. Secara klasikal, rata-rata nilai aspek keterampilan pada kelas uji coba ini adalah $86,16 \%$ ini dikarenakan setiap pertemuan aspek keterampilan siswa mengalami peningkatan. Aspek sikap dengan nilai rata-rata sebesar $83,44 \%$ pada kategori membudaya.
\end{abstract}

Kata kunci: problem based learning, tema 6 indahnya negeriku, IV, SD

Abstrack

The results of the research will lead the researcher to the success of the developed learning tools that are declared valid, practical, and effective. The research used Four-D development, namely defining, designing, developing, and distributing. The results of the research obtained from the expert validator's assessment for the product designed were in the percentage of $81 \%-100 \%$. The results of filling out the lesson plan observations made by the teacher show that the percentage of the average value is $95 \%$. The average percentage of teacher responses to the teaching materials and worksheets used is $93.83 \%$ which is in the very practical category. The results of the student response questionnaires that were distributed after the learning process also showed the practicality of the learning tools in the practical category with a percentage for teaching materials of $85.2 \%$ and $84.66 \%$ for student worksheets. Classically, the average value of the skills aspect in this trial class is $86.16 \%$ because each meeting of the student's skill aspects has increased. Aspects of attitude with an average value of $83.44 \%$ in the cultural category.

Keywords: problem based learning, theme 6 the beauty of my country, IV, SD

Copyright (c) 2021 Novri Yaldi, Ermawita

$\triangle$ Corresponding author :

Address : Institut Pendidikan Tapanuli Selatan

Email : yaldinovri@gmail.com

ISSN 2580-3735 (Media Cetak)

Phone : Nomor HP Penulis

ISSN 2580-1147 (Media Online)

DOI $\quad:$ https://doi.org/10.31004/basicedu.v5i1.568 
134 Pengembangan Perangkat Pembelajaran Berbasis Pendekatan Problem Based Learning di Sekolah Dasar - Novri Yaldi, Ermawita

DOI $\quad$ : https://doi.org/10.31004/basicedu.v5i1.568

\section{PENDAHULUAN}

Mulyasa mengemukakan bahwa guru merupakan faktor penentu pendidikan, karena yang terjadi di kelas adalah apa yang ada di dalam benaknya. Sehingga banyak berasumsi bahwa di dalam kelas, guru adalah kurikulum (Mulyasa 2014). Guru juga merupakan faktor penentu mutu dalam pengimplementasian kurikulum pendidikan, di samping faktor-faktor lainnya. Pada penerapan kurikulum 2013 guru sebagai ujung tombak yang sangat menentukan keberhasilan itu. Dalam hal ini dikatakan guru sebagai pemegang peranan atau agen utama untuk menerapkan kurikulum 2013 sehingga mencerminkan pada perencanaan serta proses belajar mengajar di sekolah .

Salah satu satuan pendidikan yang menjadi prioritas utama dalam pengimplementasian kurikulum 2013 adalah Sekolah Dasar (SD). Sebagai lembaga penyelenggara pendidikan diharapkan mampu mengembangkan perencanaan pembelajaran berupa perangkat pembelajaran yang telah dituangkan dalam silabus, lalu disesuaikan dalam penyusunan sebuah Rencana Pelaksanaan Pembelajaran (RPP). RPP ini merupakan pegangan bagi guru dalam melaksanakan proses pembelajaran untuk setiap Kompetensi Inti (KI) dan Kompetensi Dasar (KD) yang ingin dicapai (Kemendikbud 2013).

Dengan demikian, RPP harus memuat hal-hal yang berkaitan dengan melibatkan siswa secara optimal sehingga memberikan kesempatan dan mengikutsertakan mereka untuk turut ambil bagian dalam proses pembelajaran. Dalam upaya penguasaan KI dan KD tersebut sebagai mana yang tertuang dalam Peraturan Pemerintah Nomor
19/2005 Pasal 20, yang berbunyi: perencanaan proses pembelajaran meliputi silabus, rencana pelaksanaan pembelajaran, metode pembelajaran, sumber belajar, dan penilaian hasil belajar. Dalam merancang RPP perlu ada kesesuaian dengan bahan ajar. Informasi pada bahan ajar ini disesuaikan dengan karakteristik dan lingkungan siswa (Mulyasa 2009).

Memahami pentingnya perangkat pembelajaran, perlu sebuah perangkat pembelajaran yang baik sehingga mampu mewujudkan proses pembelajaran yang inovatif, inspiratif, menyenangkan serta menantang siswa. Dengan demikian, siswa mampu berpartisipasi aktif serta memberikan kesempatan yang cukup bagi prakarsa kesenian dan kemandirian sesuai dengan bakat dan minat serta perkembangan fisik juga psikologis siswa. Oleh sebab itu, hendaknya perangkat pembelajaran yang dikembangkan disesuaikan dengan kebutuhan dan karakteristik siswa terhadap pelajaran yang diberikan.

Untuk mengembangkan perangkat pembelajaran tersebut hendaknya disesuaikan dengan pendekatan pembelajaran yang sesuai dengan perkembangan siswa, sehingga dengan pendekatan pembelajaran tersebut siswa dapat memandang dan mempelajari segala peristiwa yang terjadi disekitarnya atau yang dialaminya sebagai suatu kesatuan yang utuh (holistik), dan tidak melihat semua itu secara parsial (terpisah-pisah).

Rumusan Dutch (1994), Problem Based Learning (PBL) merupakan metode instruksional yang menantang siswa agar "belajar dan belajar", bekerjasama dengan kelompok untuk mencari solusi masalah yang nyata. Masalah ini digunakan 
135 Pengembangan Perangkat Pembelajaran Berbasis Pendekatan Problem Based Learning di Sekolah Dasar - Novri Yaldi, Ermawita

DOI $\quad$ : https://doi.org/10.31004/basicedu.v5i1.568

untuk mengaitkan rasa keingintahuan serta kemampuan analisis siswa dan inisiatif atas materi pelajaran. PBL mempersiapkan siswa untuk berpikir kritis dan analitis, serta menggunakan pembelajaran yang sesuai.

Melihat kesenjangan di lapangan maka peneliti melakukan studi pustaka, ternyata hal tersebut dapat diatasi apabila guru mengembangkan silabus, RPP, bahan ajar dan LKS. Secara efektif pembelajaran berbasis pendekatan problem based learning akan membantu menciptakan kesempatan yang luas bagi siswa untuk berpikir kritis dan terampil memecahkan masalah, serta memperoleh pengetahuan dan konsep yang esensial dari materi pelajaran.

\section{METODE}

Trianto mengatakan bahwa perangkat pembelajaran adalah komponen perangkat yang digunakan untuk mengelola proses pembelajaran sehingga dapat mencapai kompetensi yang ingin dicapai secara maksimal (Trianto 2007). Menurut Daryanto, silabus disusun berdasarkan standar/ identitas mata pelajaran standar kompetensi dan kompetensi dasar, indikator, materi pokok, kegiatan pembelajaran, alokasi waktu, sumber belajar dan penilaian dengan demikian silabus yang dikembangkan juga hendaknya memuat gambaran capaian kompetensi dan proses pembelajaran sesuai dengan tuntutan setiap mata pelajaran (Daryanto and Cahyono 2014).

Muslich menjelaskan bahwa, silabus adalah penjabaran standar kompetensi dan kompetensi dasar ke dalam materi pokok, kegiatan pembelajaran, dan indikator pencapaian kompetensi untuk penilaian, alokasi waktu, dan sumber belajar (Muslich 2011). Menurut Kartono, proses pembelajaran dapat dilakukan setelah merumuskan perencanaan pembelajaran (Kartono 2014). Menurut Ahmad, RPP adalah rencana yang menggambarkan prosedur dan pengorganisasian pembelajaran untuk mencapai satu kompetensi dasar yang ditetapkan dalam standar isi dan dijabarkan dalam silabus (Ahmad 2012). Menurut Rusman (2012:7) bahwa: (1) memperhatikan perbedaan individu peserta didik, (2) mendorong partisipasi aktif peserta didik, (3) mengembangkan budaya membaca dan menulis, (memberikan umpan balik dan tindak lanjut, (5) keterkaitan dan keterpaduan, (6) menetapkan teknologi informasi dan komunikasi. Pendapat lain dikemukakan oleh Dwicahyono, bahan ajar merupakan segala bentuk bahan yang berupa informasi, alat dan teks yang dipergunakan oleh seorang guru dalam kegiatan mengajar di sekolah sehingga memudahkan siswa untuk belajar mandiri (Daryanto and Cahyono 2014). Sejalan dengan yang dikemukakan oleh Hamdani, bahan ajar adalah segala bentuk bahan atau materi yang disusun secara sistematis, baik tertulis ataupun tidak, sehingga tercipta lingkungan atau suasana yang memungkinkan siswa untuk belajar (Hamdani 2011). Istilah validitas (validity) biasanya dipakai untuk menguji suatu penelitian. Terkait dengan hal tersebut, Otto menjelaskan bahwa, validity refers to the notion that the best actually measures what it is intended to measure. This means that the best items or tasks are carefully selected to represent key developmental milestones and behaviors (Otto 2010). Maksudnya, validitas tersebut mengacu pada gagasan yang tepat 
136 Pengembangan Perangkat Pembelajaran Berbasis Pendekatan Problem Based Learning di Sekolah Dasar - Novri Yaldi, Ermawita

DOI $\quad$ : https://doi.org/10.31004/basicedu.v5i1.568

untuk mengukur sesuatu yang diukur. Ini berarti bahwa berbagai tugas secara hati-hati dipilih untuk mewakili dasar kelayakan perangkat. Pendapat lain diutarakan oleh Surapranata bahwa validitas adalah konsep yang berkaitan dengan sejauh mana tes telah mengukur apa yang seharusnya diukur (Surapranata 2006). Lembar Kerja Siswa (LKS) merupakan salah satu jenis alat bantu pembelajaran (Hidayah dan Sugiarto, 2006: 8). LKS dalam kegiatan belajar mengajar dapat dimanfaatkan pada tahap penanaman konsep (menyampaikan konsep baru) atau pada tahap pemahaman konsep (tahap lanjutan dari penanaman konsep), karena LKS dirancang untuk membimbing siswa dalam mempelajari topik. Pada tahap pemahaman konsep LKS dimanfaatkan untuk mempelajari pengetahuan tentang topik yang telah dipelajari sebelumnya yaitu penanaman konsep (Lestari 2006).

Penelitian pengembangan merupakan kegiatan pengumpulan, pengolahan, analisis, dan penyajian data yang dilakukan secara sistematis dan objektif. Pengembangan suatu produk untuk memecahkan suatu persoalan yang dihadapi. Metode penelitian yang digunakan untuk menghasilkan produk dan menguji keefektifan produk tersebut (Sugiyono 2009, 2018).

Berdasarkan tujuan penelitian yaitu menghasilkan perangkat pembelajaran berbasis pendekatan problem based learning yang valid, praktis, dan efektif maka jenis penelitian ini adalah penelitian pengembangan (development research). Menurut Putra, penelitian dan pengembangan adalah studi sistematis terhadap pengetahuan ilmiah yang lengkap atau pemahamannya tentang subjek yang diteliti (Putra 2012).
Model pengembangan yang digunakan adalah model Four-D. Model Four-D muncul pada tahun 1974 yang dikembangkan oleh Thiagarajan dan Semmel. Model pengembangan Four-D ini dipilih karena sesuai dengan masalah yang melatarbelakangi penelitian ini. Diawali dengan adanya analisis kurikulum yang sesuai dengan langkah-langkah penyusunan bahan ajar yang akan dikembangkan. Model ini terdiri dari empat tahap yaitu pendefinisian (define), perancangan (design), pengembangan (develop), dan penyebaran (disseminate).

\section{HASIL DAN PEMBAHASAN}

Peneliti banyak menemukan beberapa kendala salah satunya akses mobilisasi yang sangat jauh. Akibatnya peneliti membutuhkan waktu yang lumayan lama dalam mengumpulkan data penelitian. Pengumpulan data penelitian yang peneliti dapatkan, secara jelas akan peneliti gambarkan dalam pembahasan penelitian.

\section{Perangkat Pembelajaran}

Validator memberikan penilaian perangkat pembelajaran berbasis pendekatan problem based learning dinyatakan valid dan dapat untuk digunakan untuk pembelajaran dengan persentase $91,46 \%$.

\section{Hasil Uji Praktikalitas Perangkat Pembelajaran}

Tabel 1. Waktu Pelaksanaan Uji Coba Perangkat Pembelajaran

\begin{tabular}{clc}
\hline $\begin{array}{c}\text { Pembelaj } \\
\text { aran }\end{array}$ & Hari dan Tanggal & Waktu \\
\hline 1 & Senin, 8-5-2017 & $11.10-13.30$ \\
2 & Selasa, 9-5-2017 & $11.10-13.30$ \\
3 & Rabu, 10-5-2017 & $11.10-13.30$ \\
4 & Kamis, 11-5-2017 & $11.10-13.30$ \\
\hline
\end{tabular}


137 Pengembangan Perangkat Pembelajaran Berbasis Pendekatan Problem Based Learning di Sekolah Dasar - Novri Yaldi, Ermawita

DOI $\quad$ : https://doi.org/10.31004/basicedu.v5i1.568

Tabel 2. Uji Coba Praktikalitas dan Efektivitas

Uji coba dilakukan untuk mendapatkan nilai praktikalitas dan efektivitas perangkat pembelajaran yang dikembangkan.

\section{Hasil Observasi Keterlaksanaan RPP}

Tabel 3 Hasil Observasi Keterlaksanaan RPP

\begin{tabular}{|c|c|c|c|c|}
\hline \multirow{2}{*}{$\begin{array}{c}\text { Pembelaj } \\
\text { aran }\end{array}$} & \multicolumn{2}{|c|}{$\begin{array}{c}\text { Rata-rata } \\
\text { Penilaian Observer }\end{array}$} & \multirow{2}{*}{$\begin{array}{c}\text { Rerata } \\
(\%)\end{array}$} & \multirow[t]{2}{*}{ Kategori } \\
\hline & MS & DF & & \\
\hline 1 & 93,75 & 90,62 & 92,18 & SP \\
\hline 2 & 95,31 & 92,81 & 94,06 & SP \\
\hline 3 & 96,87 & 95,31 & 96,09 & SP \\
\hline 4 & 96,87 & 98,87 & 97,67 & SP \\
\hline \multicolumn{3}{|c|}{ Rata-rata } & 95,00 & SP \\
\hline
\end{tabular}

Keterlaksanaan RPP untuk setiap kali pertemuan berada pada kategori sangat praktis baik dari aspek tahap pendahuluan, kegiatan inti dan kegiatan penutup selama proses pembelajaran berlangsung.

\section{Angket Respon Guru}

Tabel 4. Rata-rata Angket Respon Guru

\section{Angket Respon Siswa}

Tabel 5. Rata-rata Angket Respon Siswa

\begin{tabular}{cccc}
\hline No & $\begin{array}{c}\text { Perangkat } \\
\text { Pembelajaran }\end{array}$ & Pembelajaran & Rerata $(\%)$ \\
\hline $\mathbf{1}$ & Bahan Ajar & 85,2 & Sangat Valid \\
$\mathbf{2}$ & LKS & 84,66 & Sangat Valid \\
Rata-rata & 84,93 & Sangat Valid \\
\hline
\end{tabular}

\section{a) Aktivitas Siswa}

Hasil pengamatan aktivitas siswa dengan ratarata $81,37 \%$.

\section{b) Hasil Penilaian Pengetahuan}

Hasil penilaian pengetahuan dengan rata-rata $92,43 \%$
Tabel 6. Hasil Penilaian Pengetahuan

\begin{tabular}{cccccc}
\hline $\begin{array}{c}\text { Pembelajar } \\
\text { an }\end{array}$ & $\begin{array}{c}\text { Nilai } \\
\text { Rata- } \\
\text { rata }\end{array}$ & Predikat & $\begin{array}{c}\text { S } \\
\text { T }\end{array}$ & STT & KTT \\
\hline $\mathbf{1}$ & 76,88 & B- & 12 & 3 & 82,25 \\
$\mathbf{2}$ & 77,02 & B & 13 & 2 & 87,5 \\
$\mathbf{3}$ & 83,31 & B & 16 & 0 & 100 \\
$\mathbf{4}$ & 87,3 & B + & 16 & 0 & 100 \\
Rata-rata & 81,21 & B & & 92,43 & \\
\hline
\end{tabular}

Dari tabel diatas diketahui bahwa hasil belajar siswa untuk pengetahuan terjadi peningkatan pada setiap pertemuan pembelajaran. Dengan nilai rata-rata 92,43 hasil pengetahuan.

\section{c) Hasil Penilaian Sikap}

Tabel 7. Hasil Penilaian Sikap

\begin{tabular}{ccl}
\hline Pembelajaran & Rata-rata $(\%)$ & \multicolumn{1}{c}{ Predikat } \\
\hline $\mathbf{1}$ & 75,55 & Sudah Terlihat \\
$\mathbf{2}$ & 80,55 & Sudah Terlihat \\
$\mathbf{3}$ & 82,21 & Membudaya \\
$\mathbf{4}$ & 86,66 & Membudaya \\
Rata-rata & 81,24 & Membudaya \\
\hline
\end{tabular}

Tabel 7. hasil penilaian sikap secara keseluruhan sikap siswa berada dalam kategori membudaya dari jumlah 15 siswa dengan ratarata kelas sebesar $83,14 \%$.

\section{d) Hasil Penilaian Keterampilan}

Tabel 8. Hasil Penilaian Keterampilan Siswa

\begin{tabular}{|c|c|c|c|c|}
\hline No & $\begin{array}{l}\text { Pemb } \\
\text { elajar } \\
\text { an }\end{array}$ & $\begin{array}{c}\text { Mata Pelajaran } \\
\text { dan Aspek } \\
\text { keterampilan }\end{array}$ & $\begin{array}{l}\text { Rata- } \\
\text { rata } \\
(\%)\end{array}$ & Predikat \\
\hline 1 & 1 & $\begin{array}{c}\text { Bahasa Indonesia } \\
\text { (Keterampilan } \\
\text { Membaca) }\end{array}$ & 78,51 & Baik \\
\hline 2 & 2 & $\begin{array}{l}\text { Bahasa Indonesia } \\
\text { (Keterampilan } \\
\text { Menulis) }\end{array}$ & 85,92 & Sangat Baik \\
\hline 3 & 3 & $\begin{array}{c}\text { Ilmu Pengetahuan } \\
\text { Alam } \\
\text { (Melakukan } \\
\text { Percobaan) }\end{array}$ & 85,18 & Sangat Baik \\
\hline 4 & 4 & $\begin{array}{c}\text { SBDP } \\
\text { (Membuat Kolase) }\end{array}$ & 87,4 & Sangat Baik \\
\hline \multicolumn{3}{|c|}{ rata } & 86,16 & Sangat Baik \\
\hline
\end{tabular}


138 Pengembangan Perangkat Pembelajaran Berbasis Pendekatan Problem Based Learning di Sekolah Dasar - Novri Yaldi, Ermawita

DOI : https://doi.org/10.31004/basicedu.v5i1.568

Keterampilan yang ditunjukkan pada masing-masing pertemuan pembelajaran memiliki perbedaan, begitu juga dengan aspek yang dinilai dengan nilai rata-rata $86,16 \%$

\section{Tahap Penyebaran (Disseminate)}

1. Aktivitas Siswa

Hasil pengamatan aktivitas siswa dengan nilai rata-rata $81,38 \%$.

2. Nilai Pengetahuan

Hasil nilai pengetahuan kelas penyebaran $81,07 \%$.

3. Nilai Kompetensi Sikap

Tabel 9. Hasil Nilai Sikap Kelas Penyebaran

\begin{tabular}{ccl}
\hline Pembelajaran & Rata-rata $(\%)$ & \multicolumn{1}{c}{ Predikat } \\
\hline $\mathbf{1}$ & 75,55 & Sudah Terlihat \\
$\mathbf{2}$ & 80,55 & Sudah Terlihat \\
$\mathbf{3}$ & 82,21 & Membudaya \\
$\mathbf{4}$ & 86,66 & Membudaya \\
Rata-rata & 81,24 & Membudaya \\
\hline
\end{tabular}

4. Nilai Kompetensi Keterampilan

Tabel 10. Hasil Nilai Keterampilan Kelas

\begin{tabular}{|c|c|c|c|c|}
\hline \multicolumn{5}{|c|}{ Penyebaran } \\
\hline No & $\begin{array}{l}\text { Pembe- } \\
\text { lajaran }\end{array}$ & $\begin{array}{c}\text { Mata } \\
\text { Pelajaran dan } \\
\text { Aspek } \\
\text { keterampilan }\end{array}$ & $\begin{array}{c}\text { Rata- } \\
\text { rata } \\
(\%)\end{array}$ & $\begin{array}{c}\text { Predika } \\
\mathbf{t}\end{array}$ \\
\hline 1 & 1 & $\begin{array}{c}\text { Bahasa } \\
\text { Indonesia } \\
\text { (Keterampilan } \\
\text { Membaca) }\end{array}$ & 81,48 & Baik \\
\hline 2 & 2 & $\begin{array}{c}\text { Bahasa } \\
\text { Indonesia } \\
\text { (Keterampilan } \\
\text { Menulis) }\end{array}$ & 85,18 & $\begin{array}{c}\text { Sangat } \\
\text { Baik }\end{array}$ \\
\hline 3 & 3 & $\begin{array}{c}\text { Ilmu } \\
\text { Pengetahuan } \\
\text { Alam } \\
\text { (Melakukan } \\
\text { Percobaan) }\end{array}$ & 87,65 & $\begin{array}{c}\text { Sangat } \\
\text { Baik }\end{array}$ \\
\hline 4 & 4 & $\begin{array}{c}\text { SBDP } \\
\text { (Membuat } \\
\text { Kolase) }\end{array}$ & 87,03 & $\begin{array}{c}\text { Sangat } \\
\text { Baik }\end{array}$ \\
\hline Rat & ata & & 84,56 & $\begin{array}{c}\text { Sangat } \\
\text { Baik }\end{array}$ \\
\hline
\end{tabular}

Keterampilan setiap pertemuan berada pada $80 \%$ sampai dengan $100 \%$ dikatakan sangat baik. Rata-rata nilai ini pada keempat pertemuan adalah $88,56 \%$ dengan predikat sangat baik. Secara garis besar mata pelajaran dan aspek keterampilan mendapatkan nilai sangat baik.

\section{SIMPULAN}

Pengembangan dan uji coba yang telah dilakukan terhadap perangkat pembelajaran berbasis pendekatan problem based learning, diperoleh kesimpulan: (1) Pengembangan perangkat pembelajaran dilakukan melalui beberapa tahap yaitu pendefinisian, perancangan, pengembangan dan penyebaran. Pada tahap pendefinisian diperoleh dari analisis kurikulum, analisis materi, dan analisis siswa. Secara umum dapat disimpulkan bahwa dari KI dan KD yang ditetapkan berdasarkan silabus. Pada tahap perancangan diperoleh model pembelajaran yaitu berbasis pendekatan problem based learning sehingga dihasilkan perangkat pembelajaran berupa silabus, RPP, bahan ajar dan LKS. Tahap pengembangan dilakukan dengan penilaian terhadap perangkat pembelajaran yang dilakukan oleh 5 orang validator. (2) Hasil tahap pengembangan diperoleh dari nilai validitas, praktikalitas, dan efektivitas perangkat pembelajaran. Validasi dari perangkat pembelajaran berbasis pendekatan problem based learning yang dinilai oleh 5 orang validator menunjukkan bahwa perangkat pembelajaran termasuk ke dalam kategori sangat valid. Praktikalitas yang dinilai dari pengamatan terhadap keterlaksanaan RPP oleh observer dan hasil analisis angket respon guru dan 
139 Pengembangan Perangkat Pembelajaran Berbasis Pendekatan Problem Based Learning di Sekolah Dasar - Novri Yaldi, Ermawita

DOI $\quad$ : https://doi.org/10.31004/basicedu.v5i1.568

siswa menunjukkan bahwa perangkat pembelajaran berbasis pendekatan problem based learning pada materi Tema 6 Indahnya Negeriku Subtema 2 dapat memberikan masukan kepada penyelenggara pendidikan dalam meningkatkan kemampuan siswa ini merupakan faktor penentu kualitas pembelajaran. Perangkat pembelajaran ini dapat digunakan sebagai salah satu perangkat yang mendukung pelaksanaan proses pembelajaraan yang sesuai dengan kurikulum 2013 yang telah ditetapkan pada saat ini.

\section{DAFTAR PUSTAKA}

Ahmad, Z. A. 2012. Perencanaan Pembelajaran Dari Desain Sampai Implementasi. Yogyakarta: Pedagogia.

Daryanto, and A. D. Cahyono. 2014. Pengembangan Perangkat Pembelajaran (Silabus, RPP, PHB, Bahan Ajar). Yogyakarta: Gava Media.

Hamdani. 2011. Strategi Belajar Mengajar. Bandung: Pustaka Setia.

Kartono. 2014. Modul PLPG Guru Kelas SD. Jakarta: Kementerian Pendidikan dan Kebudayaan.

Kemendikbud. 2013. Standar Proses Pendidikan Dasar Dan Menengah. Jakarta: Kemendikbud.

Lestari, B. 2006. "Upaya Orang Tua Dalam Pengembangan Keativitas Anak." Jurnal Ekonomi \& Pendidikan 3(1):17-24.

Mulyasa, E. 2009. Implementasi Kurikulum Tingkat Satuan Pendidikan: Kemandirian Guru Dan Kepala Sekolah. Jakarta: Bumi Aksara.

Mulyasa, E. 2014. Pengembangan Dan Implementasi Kurikulum 2013. Bandung: Remaja Rosadakarya.

Muslich, M. 2011. KTSP Dasar Pemahaman Dan Pengembangan. Jakarta: Bumi Aksara.

Otto, B. 2010. Language Development in Early Childhood Education. USA: Pearson Education.
Putra, N. 2012. Research and Development, Penelitian Dan Pengembangan: Suatu Pengantar. Jakarta: Raja Grafindo Persada.

Sugiyono. 2009. Pengatar Penelitian Pendekatan Kualitatif Dan R\&D. Bandung: Alfabeta.

Sugiyono. 2018. "Metodologi Penelitian Kuantitatif, Kualitatif, Dan R\&D." in Bandung: Alfabeta.

Surapranata, S. 2006. Analisis, Validitas, Reliabilitas, Dan Interpretasi Hasil Tes Implementasi Kurikulum 2004. Bandung: Rosdakarya.

Trianto. 2007. Model Pembelajaran Terpadu Dalam Teori Dan Praktek. Jakarta: Prestasi Pustaka. 